\title{
Methane Production in Heifers, Sheep and Goats Consuming Diets of Various Hay-Concentrate Ratios
}

\author{
Masaki Shibata, Fuminori Terada * Kazuo IwaSAKi ${ }^{*}$, \\ Mitsunori KURIhara and Takehiro Nishida \\ National Institute of Animal Industry, Tsukuba \\ Norinkenkyudanchi, Ibaraki-ken 305
}

(Received April 23, 1992)

\begin{abstract}
Six Holstein heifers, 10 Corriedale wethers and 11 castrated male goats of Japanese native breed were used to clarify the effects of hay-concentrate ratios on methane $\left(\mathrm{CH}_{4}\right)$ production in heifers, sheep and goats, and to find a ready method for estimating $\mathrm{CH}_{4}$ production of ruminants. The three levels of hay-concentrate were $100: 0$ $(\mathrm{H} 100), 70: 30(\mathrm{H} 70), 30: 70(\mathrm{H} 30)$, which were offered to meet around $150 \%$ of total digestible nutrients requirements. The results were as follows: 1) $\mathrm{CH}_{4}$ production was significantly different among animal species. Heifers produced about 7 times and 9 times as much as sheep and goats, respectively. 2) $\mathrm{CH}_{4}$ production was also significantly different among treatments. $\mathrm{CH}_{4}$ production in $\mathrm{H} 30$ treatment was significantly lower than that in $\mathrm{H} 70$ treatment. It was attributed to lower cellulose content and lower digestibility of fiber fractions caused by a high concentrate diet in the H 30 treatment. 3) There were no significant differences in $\mathrm{CH}_{4}$ production per various nutrient intakes among animals though their treatment effects were significant. 4) From the results of multiple regression analyses, the most useful predictors of $\mathrm{CH}_{4}$ production were the amounts of nitrogen, crude fiber and nitrogen free effects intake or those apparently digested. 5) Although estimation by multiple regression equations was more precise, the simple regression equation with dry matter intake was also highly significant. 6) From the above results, it can be concluded that $\mathrm{CH}_{4}$ production by ruminants below 1.5 times maintenance can be estimated adequately from dry matter intake (DMI) alone by the equation $\mathrm{CH}_{4}(\mathrm{l} /$ day $)=0.0305 \mathrm{DMI}(\mathrm{g} /$ day $)-4.441(\mathrm{r}=0.992)$.

Anim. Sci. Technol. (Jpn.) 63 (12) : 1221-1227, 1992
\end{abstract}

Key words : methane production, hay-concentrate ratio, heifer, sheep, goat

Recently, the rise in concentrations of socalled "Greenhouse gases", including methane, in the atmosphere and resultant global warming have been pointed out as a serious problem. According to CRUTzen et al. ${ }^{3)}$, current $\mathrm{CH}_{4}$ emission by domestic and wild animals is estimated to be about 78 teragrams/yr ( $\mathrm{Tg}$, $\mathrm{g} \cdot 10^{12}$ ), representing $15-25 \%$ of the total $\mathrm{CH}_{4}$ released into the atmosphere from all sources.

Among animals, ruminants are the major emitters of $\mathrm{CH}_{4}$. Therefore, methanogenesis within the rumen has been focused on in discussions regarding $\mathrm{CH}_{4}$ emissions from animals. However, $\mathrm{CH}_{4}$ production in ruminants is

Present address :

* Kyushu National Agricultural Experiment Station, Nishigoshi-machi, Kumamoto-ken 861-11

** National Agriculture Research Center, Tsukuba-shi 305

Anim. Sci. Technol. (Jpn.) 63 (12) : 1221-1227 1221 
strongly influenced by the level and type of diet $^{25}$ and, therefore, the relationships between dietary factors and $\mathrm{CH}_{4}$ production should be identified to estimate $\mathrm{CH}_{4}$ production precisely in ruminants.

Several attempts have been made to predict energy losses as $\mathrm{CH}_{4}$ by determining the amount of nutrients ingested or digested in cattle and sheep $2,7,9,15,16$. However, most of them require the measuring the amount of digested carbohydrate fractions for estimating $\mathrm{CH}_{4}$ production. Therefore, it is difficult to use those prediction equations for estimating global $\mathrm{CH}_{4}$ emission from ruminants by agricultural statistics. Furthermore, very few researches have dealt with cattle, sheep and goats simultaneously and tried to predict $\mathrm{CH}_{4}$ production in ruminants feeding on various levels of hay-concentrate ratios.

Our objective was to clarify the effect of hay-concentrate ratios on $\mathrm{CH}_{4}$ production in cattle, sheep and goats and to find a ready method for estimating $\mathrm{CH}_{4}$ production of ruminants.

\section{Materials and Methods}

Six Holstein heifers, 10 Corriedale wethers and 11 castrated male goats of Japanese native breed were used. Sheep and goats were divided into 3 groups and allocated to each of 3 dietary treatments as shown in Table 1, while all heifers were used for 3 treatments repeatedly. The mean body weights of heifers, sheep and goats were 401, 71 and $39 \mathrm{~kg}$ respectively.

Treatments consisted of three experimental diets. They were offered to meet around 150\% of total digestible nutrients (TDN) requirements according to Japanese Feeding Standard $^{12)}$ for heifers, $\mathrm{NRC}^{11)}$ for sheep and according to ITOH et al. ${ }^{5}$ for goats. The diets consisted of three proportions of hay wafer to concentrate : 100:0 (H 100), $70: 30$ (H 70), $30: 70$ (H 30). The hay used in this experiment consisted mainly of orchardgrass. The concentrate consisted of $30 \%$ milo, $20 \%$ barley, $20 \%$ corn, $10 \%$ wheat bran, $10 \%$ alfalfa meal, $5.5 \%$ molasses, $1 \%$ urea and $3.5 \%$ vitamins and minerals.

For regression analyses, goat data obtained from an extra period of 50:50 treatment (H 50) of hay to concentrate ratio were also used.

Animals were maintained on the experimental diets for 3 to 7 wks before a balance trial. The balance trial included a 7-day preliminary period, a 7-day metabolism trial with total collection of urine and feces and respiration measurements over 2 consecutive days in open circuit respiration chambers ${ }^{b)}$.

Proximate analyses were done for hay, concentrate, refused diet and feces by standard procedures. Starch and fiber fractions were done via procedures described by $\mathrm{ABE}^{1)}$. The nutrient composition of the hay and concentrate are in Table 2.

Analyses of variance for all animals and

Table 1. Number of animals, mean body weight, hay-concentrate ratio and dry matter (DM) intake

\begin{tabular}{|c|c|c|c|c|c|c|c|c|c|}
\hline \multirow{2}{*}{ Item } & \multicolumn{3}{|c|}{ Heifers } & \multicolumn{3}{|c|}{ Sheep } & \multicolumn{3}{|c|}{ Goats } \\
\hline & $\mathrm{H} 100$ & $\mathrm{H} 70$ & H30 & $\mathrm{H} 100$ & $\mathrm{H} 70$ & $\mathrm{H} 30$ & $\mathrm{H} 100$ & $\mathrm{H} 70$ & H30 \\
\hline Number of animals & 6 & 6 & 6 & 4 & 3 & 3 & 4 & 4 & 3 \\
\hline Body Weight (kg) & 384.6 & 397.3 & 420.7 & 69.1 & 70.3 & 73.2 & 39.1 & 39.9 & 38.0 \\
\hline \multicolumn{10}{|l|}{ Hay-concentrate ratio } \\
\hline Hay wafer (\% DM) & 100.0 & 69.5 & 30.9 & 100.0 & 20.1 & 29.9 & 100.0 & 70.0 & 29.8 \\
\hline Concentrate (\% DM) & - & 30.5 & 69.1 & - & 29.9 & 20.1 & - & 30.0 & 70.2 \\
\hline DM intake $(\mathrm{kg} /$ day $)$ & 8.1 & 8.3 & 8.1 & 1.3 & 1.3 & 1.3 & 1.1 & 1.1 & 0.8 \\
\hline
\end{tabular}


Methane Production in Ruminants

Table 2. Chemical composition of hay and concentrate

\begin{tabular}{lcccccrr}
\hline & DM & CP & CF & NFE & NDF & ADF & ST A \\
\cline { 2 - 8 } & & & & & & \\
Hay & 88.19 & 12.94 & 29.02 & 42.86 & 60.78 & 36.96 & 1.18 \\
Concentrate & 86.55 & 15.02 & 5.59 & 69.07 & 14.03 & 8.41 & 48.61 \\
\hline
\end{tabular}

DM : Dry matter, CP : Crude protein, CF : Crude fiber, NFE : Nitrogen free extracts, NDF : Neutral detergent fiber, ADF : Acid detergent fiber, STA : Starch.

treatments were conducted by the method of unequal numbers per cell without interaction of principal factors, and was done for each animal as one-way classification data. Both were computed by the library program of the Computing Centre for Research in Agriculture, Forestry and Fisheries ${ }^{13,14)}$.

\section{Results and Discussion}

Significant treatment effects were found in the digestibilities of all components, except for starch digestibility which showed a value above 98\% through all treatments. Digestibilities of dry matter (DM), nitrogen free extracts (NFE), crude fiber (CF) and neutral detergent fiber (NDF) are presented in Table 3. DM digestibility increased significantly by increasing the proportion of concentrate for all animal species. This increase was mainly attributed to the increase in the digestibility of NFE. In contrast to DM and NFE, NDF digestibility significantly decreased in heifers and sheep as the level of concentrate increased. However; there was no significant reduction in goats between $\mathrm{H} 100$ and $\mathrm{H} 70$. It is generally recognized that increases in the fiber content of diets cause a decrease in the digestibility of most components of the diet except the fiber itself and the addition of starch depressed cellulolysis $^{10)}$. It is clear that the marked decrease in NDF digestibility in $\mathrm{H} 30$ treatment was caused by high starch intake.

Table 4 shows the least square means for oxygen $\left(\mathrm{O}_{2}\right)$ consumption, and carbon dioxide $\left(\mathrm{CO}_{2}\right)$, heat and $\mathrm{CH}_{4}$ production. $\mathrm{O}_{2}$ consumption per metabolic body size (MBS, BW $\mathrm{kg}^{0.75}$ ) differed significantly among animal species as did $\mathrm{CO}_{2}$ and heat production, although no significant difference among treatments was detected. Heifers showed significantly higher values. They consumed $\mathrm{O}_{2}$ and produced $\mathrm{CO}_{2}$ and heat about $55 \%$ more per unit MBS than both sheep and goats. However, those values for both sheep and goats showed close agreement.

$\mathrm{CH}_{4}$ production was significantly different

Table 3. Digestibility of dry matter and proximate components of diets

\begin{tabular}{|c|c|c|c|c|c|c|c|c|c|c|c|c|}
\hline & \multicolumn{3}{|c|}{ Heifers } & \multirow{2}{*}{$\begin{array}{l}\text { Treat- } \\
\text { ment } \\
\text { effects }\end{array}$} & \multicolumn{3}{|c|}{ Sheep } & \multirow{2}{*}{$\begin{array}{l}\text { Treat- } \\
\text { ment } \\
\text { effects }\end{array}$} & \multicolumn{3}{|c|}{ Goats } & \multirow{2}{*}{$\begin{array}{l}\text { Treat- } \\
\text { ment } \\
\text { effects }\end{array}$} \\
\hline & $\mathrm{H} 100$ & $\mathrm{H} 70$ & $\mathrm{H} 30$ & & $\mathrm{H} 100$ & $\mathrm{H} 70$ & $\mathrm{H} 30$ & & $\mathrm{H} 100$ & $\mathrm{H} 70$ & $\mathrm{H} 30$ & \\
\hline DM & $61.9^{a}$ & $66.1^{b}$ & $69.0^{c}$ & $* *$ & $62.6^{a}$ & $65.9^{b}$ & $72.3^{c}$ & $* *$ & $61.4^{\mathrm{a}}$ & $64.9^{\mathrm{a}}$ & $72.6^{b}$ & $* *$ \\
\hline $\mathrm{NFE}$ & $70.2^{a}$ & $27.1^{b}$ & $80.9^{c}$ & $* *$ & $69.6^{a}$ & $75.1^{b}$ & $81.7^{c}$ & $* *$ & $68.1^{\mathrm{a}}$ & $74.5^{\mathrm{b}}$ & $82.3^{c}$ & $* *$ \\
\hline $\mathrm{CF}$ & $59.2^{a}$ & $56.3^{a}$ & $47.8^{\mathrm{b}}$ & $* *$ & $56.1^{\mathrm{a}}$ & $53.4^{\mathrm{a}}$ & $44.4^{\mathrm{b}}$ & $* *$ & $53.5^{\mathrm{a}}$ & $53.2^{\mathrm{a}}$ & $42.7^{b}$ & * \\
\hline NDF & $66.2^{\mathrm{a}}$ & $62.5^{b}$ & $49.1^{c}$ & $* *$ & $65.2^{\mathrm{a}}$ & $60.4^{\mathrm{a}}$ & $48.0^{c}$ & $* *$ & $63.3^{\mathrm{a}}$ & $60.3^{a}$ & $46.6^{b}$ & $* *$ \\
\hline
\end{tabular}

${ }^{11} \mathrm{DM}, \mathrm{NFE}, \mathrm{CF}, \mathrm{NDF}$ : See footnote in Table 2.

${ }^{21}$ Level of significance: ${ }^{* *} \mathrm{P}<0.01$; ${ }^{*} \mathrm{P}<0.05$.

3) $a, b, c:$ Means in the same row within each animal with different superscripts differ $(P<0.05)$ by Student's t test. 
Table 4. Least square means for daily oxygen consumption $\left(\mathrm{O}_{2}\right)$, and carbon dioxide $\left(\mathrm{CO}_{2}\right)$, heat and methane $\left(\mathrm{CH}_{4}\right)$ production

\begin{tabular}{|c|c|c|c|c|c|c|c|c|c|}
\hline \multirow{2}{*}{ Item } & & \multicolumn{3}{|c|}{ Animal } & \multicolumn{3}{|c|}{ Treatment } & \multirow{2}{*}{\multicolumn{2}{|c|}{$\begin{array}{l}\text { Difference } \\
\text { among } \\
\text { anim treat }\end{array}$}} \\
\hline & & Heifers & Sheep & Goats & $\mathrm{H} 100$ & $\mathrm{H} 70$ & $\mathrm{H} 30$ & & \\
\hline $\mathrm{O}_{2} / \mathrm{MBS}$ & $\left(1 / \mathrm{kg}^{0.75}\right)$ & $34.0^{\mathrm{a}}$ & $22.0^{\mathrm{b}}$ & $21.8^{b}$ & 26.3 & 26.3 & 25.2 & $* *$ & NS \\
\hline $\mathrm{CO}_{2} / \mathrm{MBS}$ & $\left(l / \mathrm{kg}^{0.75}\right)$ & $35.6^{\mathrm{a}}$ & $22.4^{\mathrm{b}}$ & $23.4^{\mathrm{b}}$ & 26.7 & 27.9 & 26.8 & $* *$ & NS \\
\hline Heat/MBS & $\left(\mathrm{kJ} / \mathrm{kg}^{0.75}\right)$ & $719.1^{\mathrm{a}}$ & $461.6^{b}$ & $462.0^{b}$ & 550.9 & 556.9 & 534.9 & $* *$ & NS \\
\hline $\mathrm{CH}_{4}$ & $(l)$ & $230.9^{\mathrm{a}}$ & $34.3^{b}$ & $25.2^{b}$ & $93.0^{a, b}$ & $115.0^{\mathrm{a}}$ & $82.5^{b}$ & $* *$ & $*$ \\
\hline $\mathrm{CH}_{4} / \mathrm{MBS}$ & $\left(l / \mathrm{kg}^{0.75}\right)$ & $2.6^{\mathrm{a}}$ & $1.4^{b}$ & $1.7^{\mathrm{b}}$ & $1.9^{a, b}$ & $2.2^{\mathrm{a}}$ & $1.6^{\mathrm{b}}$ & $* *$ & ** \\
\hline $\mathrm{CH}_{4} / \mathrm{DM}$ & $(l / \mathrm{kg})$ & 28.4 & 25.9 & 27.1 & $26.0^{\mathrm{a}, \mathrm{b}}$ & $29.9^{\mathrm{a}}$ & $25.4^{\mathrm{b}}$ & NS & * \\
\hline $\mathrm{CH}_{4} / \mathrm{CF}$ & $(l / \mathrm{kg})$ & 148.1 & 132.2 & 147.8 & $90.2^{3}$ & $135.2^{\mathrm{a}}$ & $202.8^{b}$ & NS & $* *$ \\
\hline $\mathrm{CH}_{4} / \mathrm{NFE}$ & $(l / k g)$ & 56.6 & 51.9 & 53.3 & $61.6^{a}$ & $59.1^{\mathrm{a}}$ & $41.1^{\mathrm{b}}$ & NS & $* *$ \\
\hline
\end{tabular}

1) MBS : Metabolic body size (Body weight $\mathrm{kg}^{0.75}$ ).

2) DM, CF, NFE : See footnote in Table 2.

3) Level of significance: NS Not significant; $* * \mathrm{P}<0.01 ; * \mathrm{P}<0.05$.

4) $a, b$ : Means in the same row within animal and within treatment with different superscripts differ $(P<0.05)$ by Student's $t$ test.

among animal species. Heifers produced about 7 times and 9 times as much as sheep and goats, respectively. In a report by GiBBs et $a l^{4}{ }^{4}$, the total population of cattle, buffalo, goats and sheep was combined into "Livestock units" using the following population multipliers : cattle $=0.8 ;$ sheep $=0.1 ;$ goats $=0.1$. It can be considered that the multipliers for "Livestock units" described above are not far from our results and are reasonable values with which to discuss $\mathrm{CH}_{4}$ emission from ruminants.

$\mathrm{CH}_{4}$ production was also significantly different among treatments. $\mathrm{CH}_{4}$ production in the H 30 treatment was significantly lower than that in $\mathrm{H} 70$ treatment. It has been shown that the amount of digested cellulose contributed to $\mathrm{CH}_{4}$ production more than that of other carbohydrate components ${ }^{9}$. Since, moreover, the conditions that promote the synthesis of microbial cells and propionate production lead to reduced $\mathrm{CH}_{4}$ production ${ }^{8)}$, it is considered that lower $\mathrm{CH}_{4}$ production in $\mathrm{H} 30$ treatment was a result of lower cellulose content and lower digestibility of fiber fractions. Promoted propionate type fermentation, usually caused by a high concentrate diet, also might be a factor in lower $\mathrm{CH}_{4}$ production as $\mathrm{LENG}^{8)}$ pointed out.

There were no significant differences in $\mathrm{CH}_{4}$ production per various nutrient intakes among animals though their treatment effects were significant. This confirms that $\mathrm{CH}_{4}$ production is a function of the nutrient intake and not of the size of the animal. $\mathrm{CH}_{4}$ production per DM intake showed its highest value in $\mathrm{H} 70$ treatment though no significant difference was detected between $\mathrm{H} 70$ and $\mathrm{H} 100$. $\mathrm{CH}_{4}$ production per CF and NFE changed with the changes in the level of concentrate. The former showed a significantly higher value and the latter showed a significantly lower value in the $\mathrm{H} 30$ treatment over others. It is considered that no significant differences among the animals and significant differences among treatments allowed the possibility of estimating $\mathrm{CH}_{4}$ production via nutrient intake for heifers, sheep and goats.

Table 5 summarizes the results of multiple regession analyses relating $\mathrm{CH}_{4}$ production to various nutrient intakes. Since $\mathrm{CH}_{4}$ is a product of the microbial fermentation of carbohydrates in the rumen and SEKINE et al. ${ }^{15)}$ found a negative relationship between DCP and 
Methane Production in Ruminants

Table 5. Results of regression analyses of methane production ( $/ /$ day) on nutrients and digestible nutrients intake ( $\mathrm{g} / \mathrm{day}$ ).

\begin{tabular}{lcc}
\hline \hline Regression equation & $\mathrm{r}^{2}$ or $\mathrm{R}^{2}$ & $\mathrm{SE}$ \\
\hline $\mathrm{CH} 4=0.0305 \mathrm{DM}-4.441$ & 98.4 & 13.6 \\
$\mathrm{CH} 4=0.0356 \mathrm{CF}+0.0450 \mathrm{NFE}-4.714$ & 98.9 & 11.2 \\
$\mathrm{CH} 4=0.0476 \mathrm{NDF}+0.0541 \mathrm{STA}-4.642$ & 98.8 & 11.6 \\
$\mathrm{CH} 4=-0.980 \mathrm{~N}+0.0646 \mathrm{CF}+0.0747 \mathrm{NFE}-4.708$ & 99.1 & 10.1 \\
$\mathrm{CH} 4=0.0470 \mathrm{DDM}-5.364$ & 99.1 & 10.1 \\
$\mathrm{CH} 4=0.0744 \mathrm{DCF}+0.0552 \mathrm{DNFE}-3.836$ & 99.2 & 9.7 \\
$\mathrm{CH} 4=0.135 \mathrm{DADF}+0.0620 \mathrm{DSTA}-4.141$ & 98.9 & 11.2 \\
$\mathrm{CH} 4=-0.960 \mathrm{DN}+0.0991 \mathrm{DCF}+0.0756 \mathrm{DNFE}-0.53$ & 99.3 & 8.9 \\
\hline
\end{tabular}

${ }^{11} \mathrm{r}^{2}$ or $\mathrm{R}^{2}$ : Coefficient of determination ( $\%$, adjusted for the degree of freedum).

2) $\mathrm{SE}$ : Standard error of residuals.

3) DM, CF, CP, NFE, NDF, STA : See footnote in Table 2.

4) MBS : See footnote in Table 4.

5) DDM : Digestible DM, DCF : Digestible CF, DNFE : Digestible NFE, DADF : Digestible ADF, DSTA : Digestible STA, N : Nitrogen, DN : Digestible $N$.

$\mathrm{CH}_{4}$ production, analyses were done by both the backward elimination method and the forward selection method for intakes of DM, N and carbohydrate components such as $\mathrm{CF}$ and $\mathrm{NFE}$ or NDF, acid-detergent fiber (ADF) and starch (STA) as predictor variables. Analyses for digestible nutrient intakes were also done in the same manner.

All nutritional components had a significant positive correlation with $\mathrm{CH}_{4}$ production $(\mathrm{r}$ > $0.87)$ although both STA and digestible starch (DSTA) intake had a low value $(r=0.64)$ compared with the other components. It is considered that $\mathrm{CH}_{4}$ production is closely related to cellulose digestion. MoE and Tyrrell ${ }^{9)}$ found differences in the contribution of each carbohydrate component to $\mathrm{CH}_{4}$ production in cattle. $\mathrm{CH}_{4}$ production per gram of cellulose digested is nearly 3 times that per gram of hemicellulose digested and 5 times that per gram of soluble residue digested. SEKINE et $a{ }^{15)}$ also concluded that the best predictor of $\mathrm{CH}_{4}$ production in calves was amounts of digestible cellular contents and digestible cell wall constituents or digestible ADF. Our data also shows a precise estimate obtained from a multiple regression equation using each carbohydrate component. However, unlike the results of SEKINE et al. ${ }^{15)}$, there was no improvement in the coefficient of determination and standard error of residuals by using carbohydrate components that were determined by the detergent method. The most useful predictor of $\mathrm{CH}_{4}$ production is the amounts of $\mathrm{N}, \mathrm{CF}$ and NFE intake or those apparently digested. The accuracy increased little when digestible nutrient intakes were used as predictors.

Although estimation by multiple regression equations is more precise, the simple regression equation with DM was also highly significant. Also, no improvement in estimation was observed when DM supplied by hay and by concentrate were used as predictors, although no data is presented in this paper. BLAXTER and ClAPPERTON $^{2)}$ showed that estimation from the total amount of digested carbohydrates was open to error because $\mathrm{CH}_{4}$ production was found to vary even when the amounts of digested carbohydrate were almost constant. KRISS $^{7)}$ also found a linear relationship between $\mathrm{CH}_{4}$ production and DM intake in cattle. According to MOE and TyRRELL ${ }^{9}, \mathrm{CH}_{4}$ production was not influenced as much by type of carbohydrate digested at low intake, such as below 1.5 times maintenance, as at higher 
intakes. Since, in our experiment, feeding level was around 1.5 times maintenance for all animals, no effects due to the nature of carbohydrate components was observed.

From the above results, it can be concluded that $\mathrm{CH}_{4}$ production by ruminants below 1.5 times maintenance can be estimated adequately from DM intake alone though a small increase in the coefficient of determination and a small decrease in the standard error of residuals will occur by using $\mathrm{N}, \mathrm{CF}$ and NFE intake or those apparently digested as a predictor. Further investigation is needed for cattle fed poor quality roughage, for lactating cows fed above 1.5 times maintenance and for fattening cattle fed an extremely high concentrate diet.

\section{Acknowledgement}

The authors sincerely wish to thank Dr. T. HaRyu, Head of Department of Animal Nutrition in our institute, for reviewing this manuscript.

\section{References}

1) ABE, A., Feed analyses based on the carbohydrates and its application to the nutritive value of feeds. Mem. Nat Inst. Anim. Ind. No. 2. 1988.

2) Blaxter, K.L. and J.L. Clapperton, Prediction of the amount of methane produced by ruminants. Br. J. Nutr., 19: 511-522. 1965.

3) Crutzen, P.J., I. Aselmann and W. Seiler, Methane production by domestic animals, wild ruminants, other herbivorous fauna, and humans. Tellus, $38 \mathrm{~B}:$ 271-284. 1986.

4) GibBs, M.J., L.Lewis and J.S. HofFMan, Reducing methane emissions from livestock: Opportunities and issues. U.S. EPA. EPA 400/1-89/002. Washington, D.C. 1989.

5) Itoh, M., T. Haryu, R. Tano and $K$. IWASAKI, Maintenance requirements of energy and protein for castrated Japanese native goats. Bull. Nat. Inst. Anim. Ind., $33: 41-50.1978$.
6) Iwasaki, K., T. Haryu, R. Tano, F. Terada, M. Itoh and K. Kameoka, New animal metabolism facility especially the description of respirational apparatus. Bull. Nat. Inst. Anim. Ind., 39: 41-78. 1982.

7) KrISs, M., Quantitative relations of the dry matter of the food consumed, the heat production, the gaseous outgo, and the insensible loss in body weight of cattle. J. Agric. Res., 40:283-295. 1930.

8) LENG, R.A., Improving ruminant production and reducing methane emissions from ruminants by strategic supplementation. U.S. EPA. EPA 400/1-91/004. Washington, D.C. 1991.

9) MoE, P.W. and H.F. Tyrrell, Methane production in dairy cows. J. Dairy Sci., $62: 1583-1586,1979$.

10) Mould, F.L., Associative effects of feeds. in World animal science, B 4, Feed science. (DRskov, E.R., ed.) 279-292. Elsevier Sci. Publ. B.V. Amsterdam. 1988.

11) National Research Council, Nutrient requirements of sheep. 4th ed. National Academy of Sciences. Washington, D.C. 1968.

12) National Research Council of Agriculture, Forestry and Fishery, Japanese feeding standard for dairy cattle. Central Assoc. Livestock Ind. Tokyo. 1974.

13) NishidA, A., Analysis of two-way classification data with unequal subclass numbers-interaction negligible. Bull. Computing Centre Res. Agric. Forestry Fishery, A 4: 45-62. 1969.

14) OKuno, C., Analysis of one-way classification data. Bull. Computing Centre Res. Agric. Forestry Fishery, A $1: 16.1967$.

15) Sekine, J., S. Kondo, M. OKubo and Y. AsAFIDA, Estimation of methane production in 6-week-weaned calves up to 25 weeks of age. Jpn. J. Zootech. Sci., 57 : 300-304. 1986.

16) Swift, R.W., J.W. Bratzler, W.H. James, A.D. TIllman and D.C. Meek, The effect of dietary fat on utilization of the energy and protein of rations by sheep. J. Anim. Sci., 7 : 475-485. 1948. 


\title{
牛，めん羊および山羊のメタン発生量に及ぼす 乾草之濃厚飼料給与比率の影響
}

\author{
柴田正貴・寺田文典 ${ }^{*}$ 岩崎和雄 ${ }^{* *}$ \\ 栗原光規・西田武弘 \\ 哌林水産省畜産試験場, 茨城県つくば農林研究団地 305
}

\begin{abstract}
反蜀家音のメタン発生量に及ぼす乾草と濃厚柌料給与比率の影響を検討し, 簡易なメタン発生量推定 式の作成を試みた。供試動物は，ホルスタイン種末経産牛 6 頭,コリデール種成去勢雄めん羊 10 頭拧 よび日本在来種成去勢雄山羊 11 頭之した，給与飼料は，オーチャードグラス主体混播牧草を原料草と した乾草ウェハーおよび当場指定濃厚飼料（尿素 $1 \%$ 入り, ペレット）であり, 乾草上浱厚飼料の給与 比率を乾物換算で $100: 0$ (H 100)，70:30（H 70)および 30:70（H 30）とした 3処理について夷験 を行なった。飼料給与量は, TDN で維持要求量の 1.5 倍を満足する量とした。 その結果, 次のような 知見を得た。 1）メタン発生量は, 動物種間に有意差か認められ, 牛の発生量はめん羊の7倍, 山羊の 9倍であった．2）メタン発生量は，H70処理にくらべて H 30 処理で有意に低い值を示した。これは， 濃厚飼料多給に伴う飼料中のセルロース含量の低下，䋐維成分消化率の低下等の要因に起因すると考元 られた．3）各種栄養成分掑取量当りのメタン発生量は，処理間に有意差老認めたか，動物種間に有意 な差は認められなかった４）重回婦分析の結果, メタン発生量推定に対する最も有効な説明变数とし て, 窒素, 粗紻維扰よび可溶無窒素物の摄取量あるいはそれらの可消化物摂取量が選択された，5）し 加し，乾物摂取量（DMI）のみを説明变数として用いても推定精度の低下は小さく，TDNで維持の

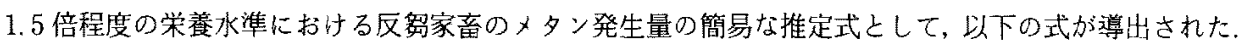
×夕ン発生量 $(1 /$ 日 $)=0.0305 \mathrm{DMI}(\mathrm{g} /$ 日 $)-4.441(\mathrm{r}=0.992)$.
\end{abstract}

日畜会報, $63(12) ： 1221-1227,1992$

現所属： *農林水産省九州農業試験場，熊本県西合志町 861-11

**農林水産省農業研究センタ一, 茨城県つくば市 305 